\title{
Implementation of Corporate Social Responsibility (CSR) Policy in the Perspective of Good Government in Karawang Regency
}

\author{
Eka Yulyana \\ Student of Doctorate Program in Administration Science \\ Padjadjaran University, Bandung, Indonesia \\ Lecturer in Department of Governmental Science, State University Of Singaperbangsa Karawang, Indonesia \\ e.yulyana@yahoo.co.id
}

\begin{abstract}
This research is conducted based on the government policy that regulates social responsibility of society as stated in some policy product. One indicator of development is the economic structure based on industry and services sectors, it appears that the sustainability of development is not only the duties and responsibilities of the government, but also the private sector / companies and even people who run activities in the field of industry and services.Karawang regency is one of the districts that switch from agrarian to industrial. The number of companies that exist in Karawang does not change people's lives from the HDI level. Karawang societiy clearly feel the impact of production activities undertaken by companies in the field of industry or services. On the basis of these researchers interested in conducting research with the title "Implementation of Corporate Social Responsibility (CSR) Policy in the Perspektive of Good Government In Karawang Regency".This research uses descriptive method with qualitative approach, because to answer how Implementation policy of CSR in Karawang regency needed description of process of involvement of the element with data collection technique, observation and interview on informant and strengthening with Focus Group Discussion (FGD) activity and data analysis. The results of research that has been donethat Corporate Responsibility Social (CSR) in Karawang regency has not run well and successfully implemented because organization, interpretation and application of $5 \mathrm{P}$ (People, Planet, Profit, Procedure and Power) not yet optimal implementation of pillar - pillars of policy implementation by involving the active role of government, private and community synergi.
\end{abstract}

Keywords-Aspects Profit; Planet; People; procedures; CSR

\section{INTRODUCTION}

Development is a business or business series of growth and change that is planned and done consciously by a nation, state and government, towards modernity in order to foster the nation according Siagian, (2006). Where in the development process is associated with the practice of allocating resources owned by a region to be able to be optimally empowered. In its development emerged the type and pattern of how the development was packed by various actors or development actors, through various programs and activities.

In poorer countries, the size of progress and development is still around basic needs, while in countries that meet these needs, development indicators will shift to secondary and tertiary factors (Tikson, 2005: 23). Tikson summarizes 6 (six) development indicators into:

1. Income per capita;

2. Economic structure based on industry and services sectors;

3. Urbanization;

4. Saving rate;

5. Physical Quality of Life Index;

6. Human Development Index (Human Development Index)

The second indicator of development is the economic structure based on industry and services sector, here it is seen that the sustainability of development is not only the duties and responsibilities of the government alone but also the private sector / companies and even people who run activities in the field of industry and services.

Corporate responsibility and responsibility towards the environment is known as Corporate Social Responsibility (CSR) and has become a warm discourse ranging from concept to practice. History proves, in the decade of the 60's many companies are highlighted because of environmental problems and human rights violations (human rights) that the company did.

The issue of corporate social responsibility (CSR) has long been emerging in developed countries, but in Indonesia, the issue has suffered intense attention from various groups (companies, governments, academics, and NGOs). The concept of CSR as an important milestone in the journey of corporate management in the world as it is in contemporary contexts but essentially the concept of social responsibility has been put forward by Howard R. Bowen in 1953. Steiner and Steiner (1994: 105-110) looked at Bowen's formulation of social responsibility undertaken by business people as a continuation of the implementation of 
various charity activities as a manifestation of human love for fellow human beings (philanthrophy).

CSR commitment and activities according to Suharto (2010: 3) essentially refers to aspects of corporate behavior including policies and programs concerning two key elements, namely:

1. Good Corporate governance: business ethics, human resource management, social security for employees, and occupational health and safety;

2. Good Corporate Responsibility: environmental conservation, community development, human rights protection, consumer protection, supplier relations, respect for the rights of other stakeholders.

According to Suharto (2010: 5) CSR is "The concern of companies that set aside profit (profits) for the benefit of human development (people) and environment (planet) in a sustainable based on procedures (procedure) the right and professional.

To minimize the negative impacts of international business and industry activities issued a draft ISO 26000 on Guidance on Social Responsibility which guides CSR for international standards. CSR based on ISO 26000 (2008) are:

"The responsibility of an organization for the effects of its decisions and activities on society and the environment is manifested in the form of transparent and ethical behavior in line with sustainable development including the health and welfare of the people; considering the expectations of stakeholders, in line with the established norms and international norms; so integrated with the organization as a whole ".

In Indonesia CSR policy is regulated in several policy products namely:

1. Law no. 40 Year 2007 regarding Limited Liability Company. ${ }^{1}$

2. Law no. 25 Year 2007 regarding Investment. $^{2}$

3. Law no. 19 of 2003 on SOEs.

4. Regulation of the Minister of State-Owned Enterprises. 4 of $2007 .^{3}$

Karawang regency is one of the areas in West Java Province and has a strategic position in the distribution of resources in West Java. Its territory is located between two big cities, Bandung and DKI Jakarta, making the Karawang regency to grow rapidly during the last 5 (five) years. The rapid development of this region also can not be separated from the high investment sector that encourages the increase of social activities and economic community in Karawang.

\footnotetext{
${ }^{1}$ Article 74 paragraph 1

${ }^{2}$ Article 15 (b).

${ }^{3}$ The Regulation of the Minister of State-Owned Enterprises shall stipulate from the amount of funds to the procedure of CSR implementation.
}

The area to be developed into an industry in Karawang regency is located on an area of 13,902.5 hectares or $7.85 \%$ of the area of Karawang regency, consisting of as can be seen in table 1.1. below this:

Table 1.1.

Industrial Area Development In Karawang Regency

\begin{tabular}{|c|c|c|c|}
\hline $\begin{array}{c}\text { Description } \\
\text { Area/Zone }\end{array}$ & Area & Location & Description \\
\hline $\begin{array}{c}\text { Industrial } \\
\text { Area }\end{array}$ & $\begin{array}{c}6.941,9 \\
\mathrm{Ha}\end{array}$ & $\begin{array}{l}\text { West Telukjambe District, } \\
\text { East Telukjambe, Ciampel, } \\
\text { Klari and Cikampek }\end{array}$ & \\
\hline $\begin{array}{l}\text { Integrated } \\
\text { Industrial }\end{array}$ & $743 \mathrm{Ha}$ & West Telukjambe District & \\
\hline $\begin{array}{c}\text { Industrial } \\
\text { City }\end{array}$ & $1000 \mathrm{Ha}$ & Cikampek District & \\
\hline $\begin{array}{l}\text { Industrial } \\
\text { Zone }\end{array}$ & $\begin{array}{c}5.217,6 \\
\mathrm{Ha}\end{array}$ & $\begin{array}{l}\text { Klari District, Purwasari, } \\
\text { Cikampek, Kotabaru, } \\
\text { Ciampel, Pangkalan, } \\
\text { Telukjambe Barat, } \\
\text { Telukjambe Timur, West } \\
\text { Karawang, East Karawang } \\
\text { and Rengasdengklok }\end{array}$ & \\
\hline $\begin{array}{c}\text { Total Zone / } \\
\text { Area }\end{array}$ & $\begin{array}{c}13.902,5 \\
\mathrm{Ha}\end{array}$ & Karawang Regency & $\begin{array}{c}\text { 7,8\% of Area } \\
\text { Karawang } \\
\text { Regency }\end{array}$ \\
\hline
\end{tabular}

Source: Department of Industry and Trade Karawang Regency, 2015

The following is the number of companies that exist in Karawang regency as can be seen in table 1.2 below.

Table 1.2

Number of Companies in Karawang Regency

\begin{tabular}{ccl}
\hline Type & Amount & \multicolumn{1}{c}{ Description } \\
\hline Industrial Area & 358 & consists of \\
Industry Zone & 379 & 511 PMA, \\
Total & $\mathbf{7 3 7}$ & 226 PMDN \\
Small Industry & $\mathbf{9 . 0 2 5}$ & \\
Supporting & & \\
\hline
\end{tabular}

Source: Department of Industry and Trade Karawang Regency, 2015

The data above shows that Karawang regency is a region that has a company, both companies with foreign and domestic investors as well as small industries that grow well in Karawang regency in the period of 20 (twenty) years shows the change of status from agricultural to industrial area.The achievement and development of the industrial sector helps the Karawang regency government to build its area for the better. The existence of the industry must have a positive impact on the development in Karawang regency, not just the negative impacts generated on the industrial activities.

Production activities undertaken by corporations can of course contribute from what they (the industrial world) definitely beroentasi so that companies get a 
profit. The benefit of the company, whether private or corporate, puts aside the profits and responsibilities of each company. CSR policy in Karawang regency government is contained in the policy product in the form of:

1. Regional Regulation of Karawang Regency Number 1 Year 2001 regarding Government Authority of Karawang Regency;

2. Decree of Regent Karawang Number 658.05 / Kep.173-Huk / 2013 About Team Roadshow Corporate Social Responsibilty Program (CSR) Karawang Regency.

Government expects CSR program can help solve social problems, such as education, health, unemployment, poverty, economic problems, such as empowering small / medium businesses and so on.

Previous research related to CSR Policy Implementation has not been done using conceptual principle of implementation policy pillar and using conceptually this dissertation will give specific contribution about new knowledge (novelty) about CSR policy implementation based on process that happened in implementation of CSR in Karawang regency by paying attention aspects developed under the definition of CSR formulated by Suharto (2010: 129): "The concern of companies that set aside a portion of their profits (profit) for the benefit of human development (people) and the environment (planet) in a sustainable based on the procedure (procedure) professional.

The research are as follows. The theoretical objectives of this research are: to analyze and find the theoretical and practical answers about the implementation of CSR policy in Karawang Regency in realizing suistainable development and developing new concept in the development of governmental science. The practical purpose of this research is to explain the practice of CSR policy implementation in Karawang Regency.

\section{RESEARCH METHOD}

This study is located in Karawang Regency.This research used descriptive method with qualitative approach, to answer How Implementation of CSR Policies in Good Government Perspective in Karawang Regency implemented is required description of the Engagement process with data collection, observation and interview as well as documentation on the informant, and Focuss Group Discussion. The informant in this research consists of key informants and informant. Based on these descriptions researcher determine informants in this study are:

1) Informants of public actor groups (local government and DPRD)

2) Informant groups of private sectors / private / entrepreneurs

3) Informant of the community actors group/ civil society.
Once the data is acquired, the data analysis used was initiated by the reduction of the data, the display presents the data and draw a conclusion.

\section{RESULT and DISCUSSION}

The study focuses on the the government policy that regulates social responsibility of society as stated in some policy product in Karawang Regency. This case is required to present what government do to overcome their problem in CSR implementation. Information about them obtained through tangible object that are directly related to private sector, government and civil society. Besides this, the data obtained also from the result of indepth interviews to the informant, and secondary data. Similarly, the information obtained from the focused group discussion involves all relevant elements of local government, parliament, private parties, and communities of various elements.

Public policy is designed to improve collaboration between government businesses and public stakeholders. In detail these four patterns of relationship are described by Figure 3.1

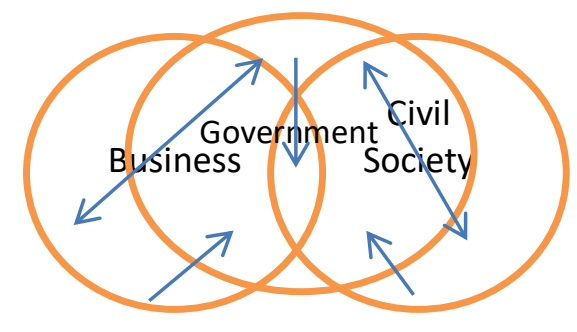

Figure 2.1 Pattern of Relationship Public Policy Analysis CSR

Information:

1. CSR in government

2. CSR in government-business relations

3. CSR in government-public relations

4. CSR in government-community relations and businesses

Previous research related to CSR Policy Implementation has not been done using conceptual principle of implementation policy pillar and using conceptually this dissertation will give specific contribution about new knowledge (novelty) about CSR policy implementation based on process that happened in implementation of CSR in Karawang regency by paying attention aspects developed under the definition of CSR formulated by Suharto (2010: 129): "The concern of companies that set aside a portion of their profits (profit) for the benefit of human development (people) and the environment (planet) in a sustainable based on the procedure (procedure) professional.

These aspects of the description can be seen as set out in table 3.1. The CSR program audit framework includes the following: 
Table 3. 1.

ASPECTS CSR Audit Progam Framework

\begin{tabular}{|c|c|c|}
\hline $\begin{array}{c}\text { Aspects } \\
\text { of }\end{array}$ & Basic Questions & Good CSR Criteria \\
\hline Profit & $\begin{array}{l}\text { 1. How big is the } \\
\text { proportion of } \\
\text { money } \\
\text { companies spend } \\
\text { on CSR? } \\
\text { 2. Where did the } \\
\text { CSR budget } \\
\text { outlay take, was } \\
\text { it accounted for } \\
\text { as a company } \\
\text { expense or taken } \\
\text { from the } \\
\text { company's gross } \\
\text { or net profit? }\end{array}$ & $\begin{array}{l}\text { 1. Budget of about } 2 \% \text { set aside } \\
\text { from net income of the company. } \\
\text { 2. The greater attention of corporate } \\
\text { policy makers to CSR budget } \\
\text { priorities }\end{array}$ \\
\hline Planet & $\begin{array}{l}\text { 1. What are CSR } \\
\text { activities related } \\
\text { to environmental } \\
\text { preservation } \\
\text { 2. What is the } \\
\text { impact on the } \\
\text { surrounding } \\
\text { environment? }\end{array}$ & $\begin{array}{l}\text { 1. The existence of real programs } \\
\text { of environmental conservation } \\
\text { The existence of } \\
\text { environmental impact } \\
\text { management facilities (eg } \\
\text { waste). } \\
\text { 3. The existence of programs that } \\
\text { have a positive impact on the } \\
\text { environment } \\
\text { 4. Negatively small and } \\
\text { controllable negative impact } \\
\text { on environmental damage. }\end{array}$ \\
\hline People & $\begin{array}{l}\text { 1. What are CSR } \\
\text { activities related } \\
\text { to improving } \\
\text { social welfare? } \\
\text { 2. What is the } \\
\text { impact on the } \\
\text { condition of the } \\
\text { community, } \\
\text { especially the } \\
\text { local community }\end{array}$ & $\begin{array}{l}\text { 1. There are real programs of } \\
\text { social services and community } \\
\text { empowerment(eg } \\
\text { strengthening health and } \\
\text { education services, providing } \\
\text { social assistance, business } \\
\text { capital and entrepreneurship } \\
\text { training, life skills). } \\
\text { 2. There is a system of social } \\
\text { protection against vulnerable } \\
\text { groups, including respect for } \\
\text { local wisdom. } \\
\text { 3. The existence of programs that } \\
\text { have a positive impact for } \\
\text { improving the quality of life, } \\
\text { livelihood and community } \\
\text { independence. } \\
\text { 4. Negatively small and } \\
\text { controllable negative impact } \\
\text { on the destruction of the social } \\
\text { system } \\
\text { (social distance, social jealousy } \\
\text { and conflict) }\end{array}$ \\
\hline $\begin{array}{l}\text { Procedu } \\
\text { re }\end{array}$ & $\begin{array}{l}\text { 1. How is the CSR } \\
\text { program } \\
\text { implemented? } \\
\text { 2. Is the process } \\
\text { carried out } \\
\text { according to the } \\
\text { correct } \\
\text { procedure? }\end{array}$ & $\begin{array}{l}\text { 1. Performed by a "separate" } \\
\text { institution from the company } \\
\text { (eg partnering with a college, } \\
\text { NGO or credible local } \\
\text { organization. } \\
\text { 2. Involve professional experts in } \\
\text { their field. } \\
\text { 3. CSR integration with company } \\
\text { policy } \\
\text { 4. Active involvement and strong } \\
\text { support from government, } \\
\text { NGOs and communities, and } \\
\text { good coordination among } \\
\text { them. } \\
\text { 5. Program planning, Monitoring } \\
\text { and Evaluation. }\end{array}$ \\
\hline
\end{tabular}

Source: Suharto, 2010
The results of in-depth interviews and the results of the discussion group forums from the involvement of all stakeholders involved in the implementation of CSR policies are collected on:

\section{Aspects of Profit}

In the profit aspect, information mining is done by presenting the question of how much proportion of money the company spends on CSR and from which CSR budget outpost is taken, whether calculated as corporate cost or taken from the gross or net profit of the company. According to Mr. Puji Isyanto as APINDO secretary who was interviewed on May 24, 2017 said that:

"Normatively, Indonesia has obliged every company to implement TJSL through a number of national regulations". But the facts in the field show the portrait of the problem, especially related to the tariff (cost contribution) that the company should allocate to realize the TJSL. Candy-BUMN No. 9 Year 2015 on Partnership Program and Community Development Program accepts TJSL First obligation, PKBL funding source may come from provision of part of profit and other legitimate sources. Second, the amount of funds set aside will be determined by the Minister / GMS. Third, the criteria of small-scaled businesses participating in the Partnership Program are having a net worth of Rp 500 million (excluding land and buildings) or having annual sales at most RP $2.5 \mathrm{M}$. Maximum $4 \%$ of net profit after tax of the previous financial year (article 8 paragraph (1)).

Most of the companies and SOEs have done just that the profit of the company not all open companies reveal the profits of the company. Therefore, the government's active role in supervision must be maximal in terms of transparency and accountable from the company.

\section{Aspects of Planet}

In the aspect of planet disclosure information is explored by questioning of CSR activities related to environmental conservation and What is the impact on the environment condition. As mandated in the Law no. 32 of 2009 on Environmental Protection and Management states in Article 68: Everyone who carries on business and / or activity is obliged to: a. provide information related to the protection and management of the environment properly, accurately, openly and in a timely manner; $b$. maintaining the sustainability of environmental functions; and c. comply with the provisions on environmental quality standards and environmental damage criteria. Mr. Dedi from Bappeda Karawang explained that:

"Some companies have been doing activities related to environmental conservation with the procurement of tree and fruit seedlings that are done by distributing to the residents to be planted, but there are also companies that still do environmental destruction by disposing of waste 
directly to the river that is used by the residents". This revelation is also reinforced by the father of Puji Ciampel residents.

Most of the company's production activities still have not run the mandate of the law on environmental protection and management, and this will continue to be addressed by monitoring and evaluation actions by related agencies to companies.

\section{Aspects of People}

In this aspect, information is extracted by asking CSR activities what is done by the company related to the improvement of social welfare and what is the impact to the condition of society especially the local community.

The basis of this information excavation refers to the implementation of Permen-BUMN no. 9 Year 2015 on Partnership Program and Community Development Program. First, the source of PKBL funds may come from the provision of part of the profits and other legal sources. Second, the amount of funds set aside will be determined by the Minister / GMS. Third, the criteria of small-scale enterprises that can participate in the Partnership Program are having net assets of $\mathrm{Rp} 500$ million (excluding land and buildings) or having annual sales of RP $2.5 \mathrm{M}$ at mostUU no. 13 Year 2011 on Handling Poor in Article 36 paragraph (1): Source of funding in handling the poor, including: $c$. Funds set aside from the company. Clarified in paragraph 2 that the funds set aside are used as much as possible for the handling of the poor. Article 41 on community participation in paragraph 3 is explained: business actors participate in providing community development funds as a manifestation of responsibility for poverty reduction.According to Mr. Puji Ciampel village community who became the manager of the region stated:

"The company set aside funds and provide opportunities for people who are in the neighborhood padik with PKBL activities conduct training with the amount of about Rp. 20.000.000, - .

While Dila's mother at the interview at her home in Ciampel Village which is the area of KIM and Surya Cipta and Peruri states:

"Directly never received any funding from the company but I heard that the company provided assistance to the village.

A similar statement was expressed by Mr.Puji whose house was in front of one of the factories in KIM Area with a half-brick house condition, he stated that:

"The local people obtain and from the company $\mathrm{Rp}$ 15.000 , - through the village apparatus but the company actually allocates funds for the community every head of the family is Rp.75.000, - so that many people refuse. Due to many problems related to funds and budgets as well as abuse of authority consequently the current village head is exposed to legal cases and dismissed by the regent."

Stakeholders should be more sensitive to the real and perceived real conditions of small communities, and fight for and seek to change their lives, rather than require companies to spend CSR funds to handle other financing such as to finance Persika football clubs.

\section{Aspects of Procedures}

Aspects of the procedure are explored by giving questions on how the CSR program is implemented and whether the process is carried out in accordance with the correct procedure. Mr. Puji Isyanto as secretary of APINDO Karawang stated:

"At the beginning of the leadership of the regents Cellica and Jimmy, the vice regent did sidak by visiting the company and providing the form of the filling out of the data including the nominal inclusion of CSR allocation figures to be given by the company". For SOPs implemented by companies most companies through HRD forums have divisions that handle CSR.

In practice the implementation of CSR policy in Karawang regency normatively found not only 4P (Profit, Planet, People and Procedure) but Power one influence on the achievement and distribution of CSR funds by utilizing chanelling and networking so that the funding is sometimes run partially.

\section{CONCLUSION}

Basically the implementation of CSR policy in the perspective of good governance in Karawang Regency has been implemented by the company. But the amount on the profit aspect of each company is different and there are still different interpretations. Aspects of the Planet, People and Procedures have also been carried out with the perceptions and initiatives of CSR fund managers. The finding that the power held can pressure the entrepreneurs to ask for CSR funds to be improved by the local government by optimizing the formation of the CSR management team so that both the target and the development target through CSR funds can be optimally absorbed and allocated on target in realizing sustainable development.

\section{ACKNOWLEDGMENTS}

Presented to the parties who have assisted in the research implementation of CSR policy in the perspective of good governance inKarawang Regency, the highest to, Prof. Dr. H. Utang Suwaryo, MA, who always encourage and motivate researchers to complete this research. To my beloved husband Andri Kuniawan SH, MH, who always patiently accompany and provide support affection to researchers in completing this research. To Dikti who has 
helped researchers in terms of funding research funding. Researchers pray that Allah will reward all support and help given. Thank you for all the encouragement and support of all.

\section{REFERENCES}

[1] Abidin, Said Zainal. 2004. Kebijakan Publik. Jakarta: Pancur Siwah

[2] Ambadar, Jackie. 2008. Corporate Social Responsibility (CSR) dalam Praktik di Indonesia, Jakarta : PT. Elex Media Komputindo

[3] Anderson. 1978. Public Policy Making. Reinhart and Wiston. New York

[4] Creswell J.W. 2009. Research Design: Qualitative, Quantitative and Mixed Methods Approaches, Third Edition. Los Angeles: SAGE Publication

[5] Denzin, N.K. and Lincoln, Y.S. 2003. Collecting and Interpreting Qualitative Materials. Second Edition. London:Sage Publications.

[6] Edward III, George C. 1980. Implementing Public Policy, USA: Congressional Quarterly Inc.

[7] Henn, M., Weistein, M. \& Foard, N. 2006. A Short Introduction to Social Research. London: SAGE Publications.

[8] Johnson and Johnson.2006 dalam Nor Hadi. 2011. Corporate Social Responsibility. Yogyakarta: Graha Ilmu

[9] Jones, Charles O. 1984. An Introduction To The Study of Public Policy, California: Publishing CompanyMonterey.

[10] 1994. Pengantar Kebijakan Publik. Jakarta : PT. Raja Grafindo Persada.

[11] Kartini, Dwi. 2013. Corporate Social Responsibility (Transformasi Konsep Suistainability Management dan Implementasi di Indonesia). Bandung: Refika Aditama.

[12] Keraf. G. Eksposisi. Grasindo: Jakarta

[13] Lingkar Studi Indonesia dalam Rachman, Nurdizal M., Asep Efendi dan Emir Wicanasana. 2011. Panduan Lengkap Penyusunan CSR. Jakarta: Penebar Swadaya

[14] Lord Holme and Richard Watts. 2006 dalam Nor Hadi. 2011. Corporate SocialResponsibility. Yogyakarta: Graha Ilmu

[15] Maxwell, J.A. 1996. Qualitative Research Design: An Interactive Approach.London: SAGE Publications..

[16] Moleong, Lexy,J. 2000. Metodologi Penelitian Kualitatif. Bandung: Remaja RosdaKarya.

[17] Muhadjir, Noeng. 2000. Metodologi Penelitian Kualitatif, Edisi IV, Yogyakarta: Rake Sarasin

[18] Pulzl, Helga and Oliver Treib. 2007. Implementing Public Policy. Handbook of Public Policy Analysis: Theory, Politics, and Methods, edited by F. Ficher, G.J. Miller, and M.s. Sidney, USA: CRC Press.

[19] Siagian, Sondang P.2006.Manajemen Sumber Daya Manusia, Cetakan Ketiga belas. Jakata : Bumi Aksara.

[20] Sugiyono. 2008. Metode Penelitian Kuantitatif, kualitatif dan R\&D. Bandung : Alfabeta.

[21] Suharto, Edi. 2010. CSR \& COMDEV (Investasi Kreatif Perusahaan di Era Globalisasi. Bandung: Alfabeta.

[22] Steiner, Goerge A., and Steiner, John F. 1994. Business, Government and Society : A Managerial Persfective, Seventh Edition, McGraw-Hill International Edition.

[23] Tachjan.2006. Implementasi Kebijakan Implementasi Kebijakan. AIPI danPuslit KP2W Lembaga Penelitian Unpad.

[24] Tikson, Deddy T.2005. Theory of underdevelopment and dependent development of economic in Indonesia, Malaysia and Thailand. Jakarta ; inninawa

[25] Wahab, S.A. 2002. Analisis Kebijaksanaan, dari Formulasi ke Implementasi Kebijakasanaan Negara. Jakarta : Penerbit Rineka Cipta. Edisi Kedua.
[26] Wibisono, Yusuf. 2007. Membedah Konsep \& Aplikasi CSR. Gresik : Fascho Publishing.

[27] Winarni SP, Tri. 2012. Kontribusi Corporate Social Responsibility dalam Upaya Penanganan Lanjut Usia: Sebuah Alternatif dalam Susetiawan (ed.). Corporate Social Responsibility, Komitmen untuk Pemberdayaan Masyarakat. Yogyakarta: Azzagrafika.

Thesis/ Desertasi

[28] Dini Suryani. 2009. The Politic of Corporate Social Responsibility. Yogyakarta

[29] Hayatullah Kurniadi.2014. Corporate Social Responsibility (CSR) Industri Ekstraktif di Indonesia (Studi Kasus CSR PT. Chevron Pacific Indonesia pada Masyarakat Minas di Provinsi Riau

Peraturan Perundang-Undangan

[30] Mentri Hukum dan Hak Asasi Manusia. 2007. Undang-undang Republik Indonesia Nomor 25 Tahun 2007 Tentang Penanaman Modal. Jakarta

[31] Mentri Hukum Dan Hak Asasi Manusia. Undang-Undang Repubik Indonesia Nomor 40 Tahun 2007 Tentang Perseroan Terbatas. Jakarta: Lembaran NegaraRepublik Indonesia Tahun 2007 Nomor 106

[32] Mentri Hukum dan Hak Asasi Manusia. 2009. Undang-Undang Republik Indonesia No. 32 tahun 2009 tentang Perlindungan dan Pengelolaan Lingkungan Hidup. Jakarta

[33] Mentri Hukum dan Hak Asasi Manusia. 2009.Undang-Undang No. 22 Tahun 2001 tentang Minyak dan Gas Bumi

[34] Mentri Hukum Dan Hak Asasi Manusia. 2012. Peraturan Pemerintah Republik Indonesia Nomor 47 Tahun 2012 Tentang Tanggung Jawab Sosial Dan Lingkungan Perseroan Terbatas. Jakarta : Lembaran Negara Republik IndonesiaNomor 89

[35] Permensos No. 13/2012 tentang Forum Tanggung Jawab Dunia Usaha dalam Penyelenggaraan Kesejahteraan Sosial. Jakarta

[36] Permen-BUMN No. 9 Tahun 2015 tentang Program Kemitraan dan Program Bina Lingkungan. Jakarta 